\title{
Dubaification in practice: an inter-scalar analysis of Belgrade Waterfront
}

Jorn Koelemaij

To cite this article: Jorn Koelemaij (2021) Dubaification in practice: an inter-scalar analysis of Belgrade Waterfront, Urban Geography, 42:4, 439-457, DOI: 10.1080/02723638.2020.1721205

To link to this article: https://doi.org/10.1080/02723638.2020.1721205

曲 Published online: 09 Feb 2020.

Submit your article to this journal

Џlll Article views: 534

Q View related articles $\llbracket$

View Crossmark data $₫$

Citing articles: 5 View citing articles $₫$ 


\title{
Dubaification in practice: an inter-scalar analysis of Belgrade Waterfront
}

\author{
Jorn Koelemaij
}

Geography Department, Ghent University, Ghent, Belgium

\begin{abstract}
Large-scale real estate development projects are increasingly often facilitated by transnational flows of capital investment and development expertise. While such projects clearly contain elements that closely correspond to classic notions of urban entrepreneurialism, the drivers and strategies behind them are rather different due to the close involvement of national level state actors, real estate developers and capital investors respectively. Against this backdrop, this paper discusses the case of Belgrade Waterfront, a large-scale mixed-use real estate development project in Serbia, developed by a company from the United Arab Emirates (UAE). It is illustrated how the foreign developer and the Serbian government are realizing the project by selectively applying a number of "Dubaiprinciples" to urban development. Based on extensive qualitative research, including interviews in Dubai, Abu Dhabi and Belgrade, it is argued that the experimental purposes of this transnational project are best understood through a combined lens of geopolitical and geoeconomic processes.
\end{abstract}

\section{ARTICLE HISTORY}

Received 30 May 2019

Accepted 21 January 2020

\section{KEYWORDS}

United Arab Emirates; Serbia; Belgrade; transnational real estate development; urban entrepreneurialism

\section{Introduction}

Real estate has claimed the top sport for capital investment, with $\$ 157.5$ bn of announced FDI recorded in 2016, following an increase of 58\% (The fDi Report 2017, fDi Intelligence).

Capital Investment in Serbia almost doubled to $\$ 4.4$ bn following a United Arab Emiratesbased real estate investor committing to jointly invest $\$ 3$ bn in the country (The fDi Report 2016, fDi Intelligence).

As a direct consequence of the shifting geographies of wealth and power since the beginning of the 21st century (Beaverstock, Hubbard, \& Short, 2004), striking new spatial patterns of FDI-flows in real estate development have arisen. This is reflected by the announcement of many large-scale, master-planned transnational real estate developments (TREDs) in recent years, including in Belgrade (Koelemaij, 2019), Cairo (Bennett, 2018), London (Greenfield, 2018) and many other cities. Looking at the sources of capital behind those TREDs, it appears that they increasingly often take place on behalf of investors and developers from the wider Global East, which refers

CONTACT Jorn Koelemaij Jorn.Koelemaij@UGent.be $\Theta$ Geography Department, Ghent University, Krijgslaan 281S8, Ghent 9000, Belgium

This article has been republished with minor changes. These changes do not impact the academic content of the article. 
to "emerging economies" in East Asia, the Middle East and Eastern Europe (fDi Markets data, 2003-2014; Müller, 2018). They thus indeed signify ongoing global geographical shifts in terms of surplus capital. There has been a fair amount of scholarly attention for transnational investments in existing real estate (Fernandez, Hofman, \& Aalbers, 2016; Rogers, 2017; Rogers \& Koh, 2017; Wong, 2017) and for the transnational, "mobile" policy elements behind large-scale real estate developments in terms of architectural design and planning concepts respectively in recent years (Knox, 2012; Olds, 2001; Rapoport, 2015; Rapoport \& Hult, 2017; Sklair, 2009). This paper, on the contrary, particularly focuses on the specific impact of crossborder capital investment behind TREDs in terms of underlying rationales and power relations. As a consequence, it is argued that there are a number of relatively new, recurring features that actually distinguish contemporary TREDs from their historical predecessors, as well as from megaprojects more generally.

The first noteworthy aspect of contemporary TREDs thus relates to its geographies. A closer look at where 21st-century TREDs take place namely shows that they are predominantly situated within the aforementioned Global East category as well, something that is also increasingly visible in the urban studies literature (e.g. Barthel \& Vignal, 2014; Dixon, 2010; Percival \& Waley, 2012). Meanwhile, resource-rich and "emerging" economies such as The United Arab Emirates (UAE), Qatar, Malaysia and China are among the main sources of TREDs-related capital investment (fDi Markets data, 2003-2014), a situation markedly different from the 1970s and 80s (Stanek, 2012). Secondly, while TREDs can obviously vary in terms of size, function, or the exact type of investment that is behind it, they generally share a mixed-use design and focus on the provision of the higher segments of the real estate market, including luxury offices, apartments, hotels or retail. Their announcement usually goes hand in hand with a "boosterist" rhetoric: the stakeholders, be it "public" or "private" ones, often stress that the development will "put the city on the map", while propagating a cosmopolitan lifestyle (Paul, 2004; Roy \& Ong, 2011). More recently, fashionable adjectives such as "smart", "eco" or "tech" are eagerly added to the marketing campaigns (Rapoport, 2014; Watson, 2014). In terms of urbanistic and architectural design as well as ideological background, they thus significantly differ from urban development models that were exported to the "third world" during the Cold War era (Avermaete, 2012; Stanek, 2012). A third distinctive feature vis-à-vis previous transnational real estate development projects is that contemporary TREDs seem to be more than ever driven by peculiarly combined speculative and authoritarian strategies in terms of their financing schemes as well as implementation (Bhan, 2014; Goldman, 2011), which frequently makes them "haunted by the specter of failure" (Shatkin, 2017, p. 214). Regarding recent South-North state-investments more generally, Haberly (2017, referring to Cohen, 2009) indicates that a number of observers have expressed fears that "often authoritarian states [are nowadays] leveraging their financial wealth to radically overturn the world economic and political order" (p. 8), and confirms that these transnational investments usually help states advancing their own national developmental agendas.

While there have been pioneering studies that have to some extent addressed the drivers and dynamics behind contemporary TREDs (e.g. Barthel \& Veignal, 2014; Brill \& Reboredo, 2018; Follmann, 2015; Nam, 2017), it is still largely unknown how and why they generally take place, and there have been few attempts so far to conceptualize 
them as a separate analytical category. Hence, this paper elaborates on the existing empirical observations on this topic, after which it focuses on the case of Belgrade Waterfront: an ongoing mixed-use project in the Serbian capital of Belgrade, developed by a UAE-based company in a way that is reminiscent of authoritarian and experimental Dubai-principles of urban real estate development (Acuto, 2010; Steiner, 2014). This case study is not only relevant in a broader perspective because the UAE appears to be the largest global provider (or, bearing in mind a number of projects that have been put on hold in recent years, at least "announcer") of TREDs between 2003 and 2014 (fDi Markets data, 2003-2014), but also since Dubai is known to be one of the more common aspirational categories when it comes to the inter-referencing practices of urban policy makers with world city-entrepreneurial ambitions nowadays (Golubchikov, 2010; Van Leynseele \& Bontje, 2019), both within and outside its own region (Barthel, 2014; Choplin \& Franck, 2014; Veignal, 2014). Van Noorloos and Kloosterboer (2018, referring to Bhan, 2014; Cirolia, 2014) argue that references to cities such as Dubai, Singapore or Shanghai often not only entail envisaged similarities in terms of design, but also in terms of the rationality and (semi-)authoritarian governance, free from the messiness of democratic politics. Section 3 of this paper will elaborate on this statement by concisely discussing how the domestic model of urban development in the UAE roughly looks like, and how it has previously been attempted to export these principles to overseas contexts.

Since the purpose of this paper is to fully address the "how" and "why" questions behind Belgrade Waterfront, there is a need to include perspectives from both the "exporting" side, in this case the Abu-Dhabi based company of Eagle Hills, and the "importing" side, in this case the Republic of Serbia. In order to do so, an agency-centric, relational analytical approach has been adopted. This approach allows to uncover the scalar power relations behind the decision-making processes of this project, as well as the exact strategies that are used by the main responsible stakeholders during the project's early implementation phase in 2015/2016. To this end, extensive qualitative research has been conducted. In total, 21 stakeholders (i.e. politicians, consultants, civil servants, journalists, academics, activists and businessmen) were interviewed in Belgrade in 2015 and 2016. These respondents were asked to reflect upon the main actors' roles, responsibilities and rationales regarding the project. These insights are supplemented by interviews with 13 real estate development experts (predominantly consultants) that took place in Dubai and Abu Dhabi ${ }^{1}$ over the spring of 2018. The main topics within this second round of interviews related to the domestic as well as overseas practices of UAE-based real estate developers within recent history in general and Belgrade Waterfront in particular. And finally, several policy and business documents have been analyzed in order to develop a deeper understanding of the impact, the framing and the extent to which Belgrade Waterfront is exceptional compared to other development projects in Belgrade as well as in comparison to other TREDs from across the globe. Within the scope of this paper, however, the Joint Venture Agreement that was issued in 2015 is by far the most relevant and telling document, as will be highlighted in Section 4 .

Against this backdrop, the overall aim of this paper is to develop a better understanding of the seemingly idiosyncratic dynamics behind contemporary large-scale TREDs. While it will be argued that these projects do share a number of more common features highlighted in the literatures on, for instance, urban megaprojects (e.g. Kennedy 
et al., 2014; Swyngedouw, Moulaert, \& Rodriguez, 2002), worlding cities (e.g. Roy \& Ong, 2011) and practices of urban entrepreneurialism (Harvey, 1989; Lauermann, 2018), the transnational capital investment that is so central to these TREDs requires a specific analytical approach. Elaborating on the "how-question", it will be shown how in the case of Belgrade Waterfront, the "global" provider of capital is also directly responsible for the implementation of the plan, which indicates the scalar hierarchies that tend to exist behind contemporary TREDs.

The largest knowledge gap in the existing literature, though, is related with the main drivers behind these projects, both on the supplying ("home") and receiving ("host") end. Knowing that TREDs are generally prone to fierce criticisms and vulnerable to failures, why would stateand private actors respectively want to become involved in them in the first place? Can the investment patterns and practices largely be explained by neo-Marxist theories on (geo) economic rationales such as spatial fixities or speculative "high risk, high gain" investment strategies, or are there underlying (geo)political rationales that are de facto dominant?

The remainder of the paper is organized as follows. The next section discusses a number of recent insights about present-day large-scale real estate development projects, paying specific attention to those that can be categorized as TREDs. While focusing particularly on the aforementioned motives and strategies behind them, the paper will also reflect on the extent to which TREDs correspond to concepts such as world city entrepreneurialism and worlding cities. Section 3 discusses the politicalinstitutional context of the UAE, and how this relates to both their domestic and overseas real estate development practices, also referred to as the Dubai-model of urban development. Section 4 reveals the main stakeholders and some noteworthy events that have thus far occurred in the Belgrade Waterfront project, while it provides a number of the most illustrative quotes from the interviews which reveal both the power relations, responsibilities and strategies behind the project. Furthermore, Belgrade Waterfront will as well be situated within the existing literature on TREDs and the urban and world city entrepreneurialism discussed in Section 2. We conclude the paper by highlighting that the overall logic behind many TREDs (1) can only be understood by jointly looking at experimental geopolitical and geoeconomic drivers and (2) increasingly relates to the exporting and importing of authoritarian principles of urban planning.

\section{Drivers and conditions of experimental transnational investor urbanism}

As discussed in the introduction of this paper, large-scale, master-planned urban developments are not necessarily new phenomena. There are, however, important differences between previous megaprojects and contemporary ones: while the high-modernist, master-planned real estate projects that were constructed in the postwar (e.g. Europe, United States) and the post-colonial (e.g. Sub-Sahara Africa) contexts of the twentieth century were largely built according to utopian ideas of social justice, contemporary projects tend to focus on expounding wealth and privilege (Moser, 2019; Stanek, 2012; Van Noorloos \& Kloosterboer, 2018; Watson, 2014). Contemporary projects, including most TREDs, have thus been described as "city doubles" (Murray, 2015), since its mixeduse yet luxury-oriented offices and apartments form a sharp contrast with its more modest surroundings. This trend clearly relates to both the increased inter-urban competition as a result of dominant "neoliberal" ideas and "entrepreneurial" strategies 
amongst policy makers and politicians, and the increased circulation and fast implementation of architectural designs and urban policies, all of which received significant scholarly attention in recent years (Harvey, 1989; Knox, 2012; Lauermann, 2018; Peck, 2013, 2014; Rapoport, 2014). Contemporary large-scale real estate development projects have also frequently been framed in light of global city aspirations, meaning that they are supposed to eventually improve a city's position in the global inter-urban network of advanced producer services, infrastructure, investments or top-level consumer amenities and services (Van Leynseele \& Bontje, 2019; Van Meeteren, Derudder, \& Bassens, 2016).

In addition to the often rather similar esthetic and functional features, the underlying strategies, power relations, and decision-making dynamics behind the implementation to a certain degree show similar tendencies as well. One recurring element that has been emphasized is that contemporary large-scale developments often go hand in hand with state-rescaling practices (Golubchikov, 2010; Lauermann, 2018; Shatkin, 2017). Contrary to general assumptions that cities increasingly become global actors (Oosterlynck et al., 2019) and thus possess more and more decision-making power, large urban developments, especially in the context of the Global East, are usually both initiated and facilitated by central state-level actors. The active role of a national developmental state regarding speculative large-scale urban development has for instance been highlighted in a widespread number of cases, including East Asian cities such as Tokyo (Saito, 2003) and Seoul (Shin \& Kim, 2016), Southeast and South Asian cities such as Jakarta and Kolkata (Shatkin, 2017) and post-Soviet cities such as Astana (Koch, 2013) and St-Petersburg (Dixon, 2010). Kennedy et al. (2014), looking into a number of large-scale urban development projects, albeit not necessarily real estate projects, in Brazil, India, Peru and South Africa, likewise conclude that "in all of our cases, local governments are not driving the process of economic development" (p. 4). Based on those previous observations, it can be argued that large-scale real estate development projects that are associated with notions such as "world city entrepreneurialism" (Golubchikov, 2010) or "worlding cities" (Roy \& Ong, 2011), are in fact often facilitated by stakeholders acting on behalf of central governments. This particularly applies to contexts that are characterized by an above-average authoritarian state, as Shatkin (2017) has illustrated in his comparative analysis of Jakarta, Chongqing and Kolkata, although this is not a guarantee for projects to materialize. Local government actors, in turn, are to varying degrees responsible for executing the projects, generally in close co-operation with private partners.

As soon as large-scale urban real estate development projects contain a formative transnational investment element, thus becoming TREDs according to our definition, state-rescaling processes become even more fuzzy and complicated, yet increasingly interesting to explore. Here, it seems to depend very much on the context whether the capital providing "global" actors can act and decide more or less freely in terms of design and implementation, or that local-level state actors or social movements actually have sufficient power to adjust (Dixon, 2010) or frustrate the project to such an extent that the investor eventually pulls back (Brill \& Reboredo, 2018). One should also bear in mind here that in "late-development" contexts, the involved real estate actors are often less institutionalized, meaning that powerful individuals can simultaneously take on multiple roles (Van Noorloos \& Kloosterboer, 2018). In other words, the aforementioned scalar hierarchies and power relations do in fact rely much on path dependency, and the same applies to the degree to which TREDs are eventually successfully developed. 
In spite of the initial eye-catching announcements and large advertising billboards, large-scale urban developments and TREDs alike thus regularly result in unused or underused high-end properties (Cain, 2014; Goodfellow, 2017) or even empty and abandoned construction sites (Barthel \& Vignal, 2014; Brill \& Reboredo, 2018). Hence, Rapoport (2014), Watson (2014) and Kennedy and Sood (2016) have addressed them as "utopian dreams", "urban fantasies" and "tabula rasa fantasies" respectively (see also Datta, 2015). In those cases where they do eventually - to a certain extent - materialize (see Keeton \& Nijhuis, 2019), it has been found that the projects are frequently facilitated by "regulatory flexibility" (Follmann, 2015; Nam, 2017) meaning that (semi-)authoritarian central governments are indeed closely involved in paving the way for "special purpose" urban developments that are framed as being of national importance (Goldman, 2011; Koelemaij, 2019). While megaprojects, also in the European context, generally tend to occur by following exceptional and depoliticized practices and justifications, thereby setting aside usual planning procedures (Swyngedouw et al., 2002), the extent to which this "urban informality as a mode" (Follmann, 2015; citing Roy, 2009) can happen depends not only on the level of democracy within a country, but also on the existing local planning institutions and the decision-making power that they possess. Another determining contextual factor related to how exactly large-scale projects are being implemented and which role the central government plays in it, is the extent to which urban land is publicly owned (Haila, 2000).

In addition to the variety of findings regarding the scalar relationalities, roles and strategies behind TREDs, or in other words the how-question, there are also different readings of the key drivers behind these phenomena. Why do they happen, who benefits, and in which ways? Besides economic speculation and the continuous searches for new spatial fixes (Bok, 2018), which to a certain extent may explain the logics of TREDs on behalf of the investor, it is the potential (geo)political gains that are behind them which make these projects actually more experimental. According to Lauermann (2018), contemporary experimental urban entrepreneurialism indeed often occurs in parallel with speculative growth strategies, which implies that return on investment criteria are less prioritized.

These observations correspond to most findings on contemporary TREDs, which can thus be signified as accurate examples of contemporary urban entrepreneurialism, which contains prominent (geo)political elements alongside the expected economic motives. Büdenbender and Golubchikov (2016), who argue that real estate and geopolitics are closely related to one another in multiple ways, state that one should not underestimate the soft, symbolic power that comes along with TREDs, since they clearly contribute to the image of a state beyond its national boundaries. Besides this soft geopolitical power, however, TREDs can also be a part of more concrete wider bilateral deals, and one should thus be careful not to perceive them as isolated projects. As Koch (2013, p. 121) concludes based on her study of Ankara-inspired experimental real estate development in Astana: "the heightened focus on political Islam and resource economies in the post-9/11 geopolitical order means that such an undertaking must necessarily account for the relationship between urban development, energy geopolitics, and authoritarianism." In a slightly different regard, Dixon (2010), who discusses the Baltic Pearl project in St Petersburg, emphasizes the bilateral agreements that exist between China and Russia, and how that has resulted in this TRED. She states that while the Shanghai-based investor 
might indeed be looking for profits outside its saturated domestic market, it simultaneously holds close ties to the central government. The latter actively encourages the project since they hope to establish a broader strategic economic base in Northeastern Europe, while the eye-catching architecture might also lead to symbolic capital, which could eventually result in smaller spin-off real estate projects, and could thus benefit other Chinese developers with transnational aspirations.

Watson (2014) and Van Noorloos and Kloosterboer (2018), while also mentioning the desire of global surplus capital to find new spatial fixes and investment frontiers in the context of decreased profit margins elsewhere (see also Brill \& Reboredo, 2018), similarly stress that symbolic power plays a role on the receiving end, referring to TREDs in African cities. Involved state-actors, they argue, aspire to use property development in order to establish their city as a modern, globally connected place that must become appealing to global elites, like Dubai has successfully achieved in the past (Acuto, 2010). In a study of Phnom Penh, Nam (2017, p. 661) equally argues that "profit alone tells us very little about how construction and real estate practice occurs or what processes drive real estate capitalism forward (Appel, 2012; Haila, 1997)". Rather, she emphasizes that the TRED-practices she observed are in fact very experimental, characterized mainly by trial and error attitudes, social imaginaries and interconnections (see also Percival \& Waley, 2012). Searle (2014) states that Indian real estate development has become a tool for capitalist accumulation by international financiers, but at the same time stresses that that there are highly political processes behind it: while the state is a key actor facilitating all sorts of privatizations, "real estate investors' and developers' struggles over value are not only about price, but about power, prestige and practice" (p. 62). This corroborates the findings of Shatkin (2017), who, based on research in East, Southeast and South Asia, argues that due to the dramatic growth in land values, central governments increasingly "see real estate markets as a strategic realm in which to build regimes and legitimize their rule" (p. 59).

Geopolitical and political motives can thus exist amongst the transnational investor/ developer and the receiving central or local government alike. At the same time, it seems that for both parties, those often co-exist alongside (geo)economic circumstances or strategies, especially when TREDs are part of a broader bilateral deal. The two are, in other words, inter-related when it comes to TREDs, which corresponds to the argument put forward by Cowen and Smith (2009). Furthermore, it was already mentioned that it repeatedly turns out that many TREDs that are being announced are, for a variety of reasons, ultimately either significantly adjusted or canceled entirely. Hence, it is argued that while urban entrepreneurialism has thus far mainly been regarded as a speculative practice with a primary focus on economic growth, contemporary TREDs can perhaps better be understood as an experimental practice that focuses on both intangible as well as strategic political gains. This is why in the remainder of this article, the term "experimental-investor urbanism" will be coined as a concept synonymously to TREDs.

The previous paragraphs have highlighted some of the pioneering literature on TREDs, with a particular focus on "how" and "why" they happen. Based on this review, we have addressed a number of overlapping features that have been observed in TREDs from across the globe. There are, however, still some fuzzy elements that need to be further unpacked. In order to obtain more specific insights into those matters, there is 
a need for further critical case studies that thoroughly explore why this particular form of "experimental-investor urbanism" emerges in the first place, and how TREDs are generally being implemented in terms of scalar hierarchies. An agency-centered approach can help sharpening the analytical lenses here, which is also emphasized by Harrison and Hoyler (2018) in their edited volume on Doing Global Urban Research. They argue that after having asked and answered the "who-questions", questions that begin with what and where will help defining the scale and scope of their agentic role in global urban processes, while those starting with how allow to uncover the strategies and mechanisms that enable the actor(s) to fulfil this role, and why questions help to unpack their motivations and interests (p. 227). Van Noorloos and Kloosterboer (2018), who studied large-scale real estate development projects in multiple African countries, likewise state that further research on this topic "should follow the trans-local connections more closely in order to allow for a more relational and heterogeneous view" (p. 16). It is only then that we can unravel the complexity of state actors that shape our future urban environments and its consequences. In the remainder of this paper, exactly those questions will be addressed regarding the Belgrade Waterfront project. Prior to providing further details on this particular development, however, it is essential to look closer into the domestic real estate development practices within the UAE, and how exactly their "model" has actively been exported transnationally in recent years.

\section{Authoritarianism and real estate: exporting the Dubai-model}

The UAE, and especially Dubai, has witnessed spectacular urban development from the early 1970s onwards. Unlike the capital city of Abu Dhabi, whose economy is largely reliant on the Emirate's large oil reserves, Dubai was developed under the supervision of Sheikh Mohammed bin Rashid Al Maktoum following the "build it and they will come" strategy, thus focusing on speculative real estate-based global city-formation (Kanna, 2011). Apart from the superlative-(st)architecture that was built to attract attention and put the city "on the map", Dubai developed itself as the wider region's main tourism and logistics hub, while it was one of the world's pioneers regarding the creation of investorfriendly and thematic free zones that have since been copied in other cities throughout the globe. Domestic real estate development has particularly been carried out by two de facto state-owned property companies: Nakheel and Emaar (Buckley \& Hanieh, 2014; Elsheshtawy, 2019; Ulrichsen, 2016). The founder and chairman of the latter, Mohamed Alabbar, has been regarded as one of the three key figures besides sheikh Mohammed bin Rashid, which has also been referred to as the triumvirate behind Dubai Inc., and which fulfilled an important executive role in Dubai's neoliberalization processes up until 2009 (Kanna, 2011). In that capacity, he has been responsible for the construction of the eyecatching skyscraper Burj Khalifa and the enormous Dubai Mall.

The rapid and large-scale urban developments within the Gulf Region in general, and in Dubai in particular, closely correspond to the earlier discussed common contemporary features of experimental-investor urbanism. This is particularly the case since eyecatching real estate projects, usually designed by global experts and executed by government-related business conglomerates or developers, simultaneously serve as a way in which the family-state system legitimizes its ideology and its rule, and as an alleged vehicle to attract investment in other sectors of the economy (Hanieh, 2018; Kanna, 
2011). As Kanna (2011) puts it: "No Gulf country has been as aggressive in advancing top-down, large-scale institutional urbanism (Lefebvre 2003, 79) as the United Arab Emirates (UAE)” (p. 80).

Previously, real estate development projects in Dubai have critically been classified as being "hyperreal", referring to the fact that those glossy architectural designs should primarily be interpreted as materialized, or even unmaterialized (Sommerlad, 2014) symbolic capital and power. Such hyperrealities are seen as the ideal means for political legitimization and the stabilization of given structures of power and rule, specifically in neo-patrimonial, top-down and authoritarian regimes such as the UAE, which lack democratic legitimacy, participatory planning and equity (Steiner, 2014). The monopoly position of the ruling court in terms of real estate development, and the close overlap between politics and business, is therefore inextricably linked to the unparalleled speed of construction and urban development within the Emirates (see also Brorman Jensen, 2014). Other criticisms regarding urban development practices in the UAE relate to its underlying social exclusion and inequality (Acuto, 2010; Kanna, 2011) and the lack of a coherent spatial planning vision behind the often unreliable flashy images and brochures (Bromber, Krawietz, Steiner, \& Wippel, 2014; Ponzini, 2019).

Several Gulf scholars emphasize that Dubai should by itself be seen as a "hybridity": an assemblage of local and transnational networks and flows, crystallizing in a specific context (Lieto, 2019), and that one should thus avoid foisting Western stereotypes upon it (Kanna, 2011). However, they also often admit that there is "an indeniable Dubai effect" (Kanna, 2011, p. 11) that has been felt across the region, particularly from the late 1990s onwards. While others have been discussing a "Dubai-model" by focusing on its port-city linkage (Akhavan, 2019) or its Free Zone development (Hertog, 2019), the direct and indirect impact of Dubai across the wider MENA-region mainly relates to the city's prominent focus on large-scale real estate development (Elsheshtawy, 2019). On the basis of a thorough literature review, supplemented by interviews with Dubai-based real estate experts, it can be argued that real estate development in Dubai can first and foremost be characterized by eye-catching transnational (st)architecture and the immense speed at which it unfolds, thus mainly characterized by authoritarianism, nepotism, exclusion, speculation, non-transparency and imaginary visualization.

Moreover, the aftermath of the global financial crisis demonstrated that the speculative real estate-based urban economic development of Dubai was not economically sustainable. In October 2008, as the real estate bubble burst, many ongoing construction projects in the UAE and in other parts of the world where UAE-based developers were involved, came to a sudden halt. According to some observers, the immediate post-crisis years therefore led to a number of institutional changes behind "Dubai Inc.", and consequently heralded the quasi-end of the speculative urban development model that characterized the "build it and they will come-era" (Elsheshtawy, 2019). More recently, however, the overseas impact of the Dubai-model as it has been developed during the pre-crisis years, seems to have made a comeback, be it through direct intervention (Hanieh, 2018; Ponzini, 2019) or rather indirectly through interreferencing (Nastasi, 2019; Van Leynseele \& Bontje, 2019). As Elsheshtawy notes: "One must also consider the substantive impact of Dubai's mode of development on the rest of the region and other parts of the world. This hyper-reliance on real estate as a major driver for city growth foretells a phenomenon I have dubbed 'Dubaization'” ( $p$. 
252). Based on the interviews that were conducted with real estate experts in Dubai, it indeed appears that after a few years of relative inactivity and a number of institutional as well as market changes, most developers that remained active tend to largely stick to their old habits in terms of how they address real estate development, both domestically and transnationally.

While real estate development is but one of the transnational foreign direct investment categories on behalf of the UAE's family state-related business elites, it is definitely the most eye-catching one. It has already been noted that the UAE is generally regarded as the largest cumulative source of TREDs in the 21st century (fDi Markets data, 2003-2014), even though a significant number of projects that were announced during this period have been put on hold. A number of previous studies have illustrated how mainly Dubai-based, government-related developers, such as Emaar, have predominantly been active in the Middle East and North Africa (MENA) region, exporting their domestic "Dubai-model" principles of top-down, authoritarian and, indeed, experimental urban real estate development to foreign contexts (Ponzini, 2019). This has, to some extent, been observed in Casablanca, Tunis (Barthel, 2014), Cairo (Adham, 2014), Damascus (Clerc \& Hurault, 2010; Veignal, 2014) and Khartoum and Nouakchott (Choplin \& Franck, 2014), to name a few, as well as in Delhi (Follmann, 2015). While some variety amongst them obviously exists in terms of design, implementation and finance (Molotch \& Ponzini, 2019), almost all of these projects actively involved macro-level state actors. Besides, and as already highlighted, the originally presented visualizations were frequently either radically altered or even entirely withdrawn. Those failures have been ascribed to a variety of reasons, including political unrest, financial issues or local resistance from civil society groups. Despite the limited success rates of these projects, Dubaibased developers are thus still actively searching for overseas investment opportunities, as has been confirmed by several of our respondents as well as business reports that were consulted (e.g. Emaar, 2017).

At first sight, it seems that the vast majority of countries in which the Dubai-model of urban development is being propagated and practiced through transnational agreements, are not particularly highly-ranked in global democracy-rankings. In other words, there seems to be a connection between the geographies of TREDs and the global rise of authoritarianism (see also Bogaert, 2018; Koch \& Valiyev, 2015) in which governments actively adapt to the realities of neoliberal global markets while using large-scale urban developments to consolidate authoritarian political configurations (Hertog, 2019; Van Noorloos \& Kloosterboer, 2018). The next section reveals how this relational interplay has occurred in the case of Belgrade Waterfront.

\section{Behind the Frontline of the Belgrade Waterfront}

In 2012, plans were announced to develop a large-scale mixed-use waterfront project along the Sava River, on a piece of state-owned land in central Belgrade. For more than a century, there have been plans to develop real estate on this very location, but for a variety of reasons this never actually happened. Hence, the site was rather derelict and semi-abandoned for years, and mainly contained old railway tracks aside from a small number of residential settlements. Within 30 years' time, the 80 -hectare area is supposed 
to contain a $200 \mathrm{~m}$ high tower, a large shopping mall and mixed-use, high-end spaces for working, living and leisure. Soon after, in 2013, several marketing campaigns were launched, making the project's announcement visible across several locations in Belgrade. Around the central railway station and thus the future construction site, large billboards emerged as well as dozens of flags indicating the name of the developer: the Abu Dhabi-based company Eagle Hills.

Besides the eye-catching marketing campaigns of the project, its announcement triggered a lot of attention across the country and beyond, due to the fact that Eagle Hills promised to invest the striking amount of 3.5 billion dollars. Eagle Hills is a relatively new company that took over the former projects of $\mathrm{Al}$ Maabar International Investments Company, a transnational real estate developer with ongoing activities in Bahrain, Jordan, Morocco, Oman and Ethiopia. Along with this name change, the company got a well-known new chairman in 2014, namely the aforementioned Mohamed Alabbar.

On behalf of the Serbian government, the Waterfront project is inextricably linked to two key figures: Aleksandar Vučić, who was running in the electoral campaign to become the mayor of Belgrade in 2012, and although he did not win these, he eventually rose to the position of deputy prime minister, prime minister and eventually president. In those capacities, he was able to arrange the investment deal with Alabbar and his network. The second person that has been associated with the implementation of the project from the very beginning is Siniša Mali: a close political ally of Vučić, who did become Belgrade's mayor in 2014, after which he obtained the position of Finance Minister in 2018. In more or less the same period, according to several media sources and policy documents, further bilateral agreements were made between the UAE and Serbia, relating to defense and food industries as well as aviation (Wright, 2015). Serbia's national air carrier, for instance, is currently for 49 per cent owned by Abu Dhabi-based Etihad Airways. Precisely this type of "elite agency", which seems to be common behind TREDs, has been noted more often in the real estate-related urban policy mobilities literature (e.g. Hertog, 2019; Moser, 2019).

While the project received fierce criticism from a selective part of the city's population from the very outset for being too detached from the actual spatial context, too much topdown, and not transparent enough, Mali and the rest of the ruling political elite continued promoting the project at international real estate fairs such as the MIPIM in Cannes, while facilitating Eagle Hills' demands in developing the project as much as they could. One of the main, and simultaneously most contested measures that were taken, were the changes that were made in the existing legislation regarding real estate construction. While repeatedly asserting the "national importance" of Belgrade Waterfront, emphasizing the number of jobs and economic growth it will create, a Lex Specialis was introduced on behalf of the Serbian government. This new law provides Eagle Hills with a significant freedom while developing the project (for a more detailed overview of the changes that were conducted in existing planning and legal documents, see Grubbauer \& Čamprag, 2018).

Although even the most basic information was categorized as classified in the beginning, the contract that was signed in 2015 in order to establish the joint venture agreement between the Republic of Serbia (RoS) and Eagle Hills and its associated investment vehicles was revealed to the public after increasing demands and conspiracy 
theories from opponents and activist groups. This document reveals a number of details, including the fact that the RoS has been provided with a number of loans on behalf of the latter, and with that money they need to prepare the construction site and prepare all basic utility infrastructure and services. Eagle Hills, in turn, are allowed to make adjustments to the plan throughout its implementation, while they, or rather third parties belonging to what has been called as the "Global Intelligence Corps" (Olds, 2001; Rapoport \& Hult, 2017) that are hired by them, exclusively provide services such as project design, development and managing services and sales and marketing to the company. One example is the well-known American architectural firm Skidmore, Owings and Merrill (SOM), who are appointed as the designers of "Kula Belgrade", the project's eye-catching skyscraper (see also Koelemaij, 2019).

This hierarchical division of labor is not without its tensions. As one of our government-related respondents in Belgrade indicated, it frustrated him to some extent that they were not responsible for the advertisement campaigns. He admitted that they were not much in favor of them, bearing in mind the public reaction it would provoke, but that "they (referring to Eagle Hills) provide the finance and they are taking care of the project, because that's what they do the best. We cannot do that" (Mayor's Office Chief of Staff, Belgrade). Later in the interview, he again justified this autonomy in terms of decisionmaking, by stating that: "That is investor urbanism ...... In this kind of world, you have multinational companies, big companies that are having their businesses all over the world. They already have that knowledge, you know, they have that know-how".

The power relations behind the implementation of Belgrade Waterfront can thus best be understood through a scale-based hierarchy, in which the global developer possesses the authority to take the main decisions, being facilitated by the political actors related to the RoS's central government, while the local actors are predominantly being bypassed or solely limited to executive tasks. On the other hand, however, the national and local government should not be seen as being separate from one another. Vučić' SNS-party possesses the majority on both levels, and there are close ties and even overlaps between for instance the former mayor of Belgrade and his direct employees, and the Belgrade Waterfront Company supervisory board. In a sense, this corresponds to Lauermann's (2018) observation that contemporary urban entrepreneurialism can best be understood by focusing on topological relations and (trans-)locally operating actors, although it should also explicitly be noted here that national law is still instrumental if public funds are accessed and the state seeks to extend exceptional benefits to private investors and international business elites (Grubbauer \& Čamprag, 2018). The findings regarding the how-question behind this case study are furthermore in line with Van Noorloos and Kloosterboer (2018) when they state that real estate actors in late-development contexts are less institutionalized, which allows them to take on different roles simultaneously.

Finally, the most challenging questions to answer regarding this project are, again, the actual why-questions behind Belgrade Waterfront, on behalf of the political elites of both the UAE and Serbia respectively. Here, it is essential to mention that Belgrade Waterfront was announced after a number of wider bilateral agreements between the two countries were made, which are largely the result of the personal relationship between the political leaders. This strategy is not exceptional, as has been confirmed by nearly all real estate experts that were interviewed in Dubai and Abu Dhabi: "Financial feasibility is often not the first concern of such transnational projects... It could be that it is more related to 
politics. Then it goes like 'I want to have landing slots', or 'I want to sell more oil and gas, and in return we can construct something nice for you guys" (Development Consultancy Partner, Dubai). Multiple respondents furthermore argued that while feasibility studies are usually less determinant for UAE-based real estate developers in general, it is always extremely challenging to develop large-scale TREDs, let alone to achieve return on investment easily. Although the two largest Emirates are indeed looking for ways to diversify its economies by globally investing surplus capital, and are thus continuously looking for emerging growth markets to invest in, the logics behind a spatial fix cannot be understood without closely scrutinizing their political aspects. While these combined political and economic rationales tend to apply to megaproject developments more generally (Flyvbjerg, 2014), their co-existence appears to be even more explicit when it comes to greenfield foreign direct investments such as TREDs. Besides, the symbolic capital that comes with spectacular urban developments (e.g. Büdenbender \& Golubchikov, 2016; Hertog, 2019; Steiner, 2014) was confirmed by multiple respondents: "I think it (transnational real estate development) is effectively a good marketing tool for the UAE. People need to know more about them, so they want to effectively increase their presence in these areas, and be known for it. So that people say 'ok, this company, this is an Emirates company. Ok fine, what's in the Emirates?' And they will bring other business here. And so on. That is a tremendously important part of how the economy here works. To effectively market it" (Senior Analyst Real Estate Consultancy, Dubai). This strategy is in line with Haberly's (2017) aforementioned statement on how South-North investments can actually advance the host-country's own national development agendas.

For the political elites in Serbia, there are similar symbolic gains alongside importing capital investment and know-how. Belgrade Waterfront serves as a scale-making project for Vučić' administration (Koelemaij, 2019), and thus strengthens and asserts the current rulers' power position, even though they provide Eagle Hills with so much freedom in terms of the project's development. Despite all the controversies and resistance regarding the project, Vučić got reelected in 2017. Furthermore, the fact that Siniša Mali has traveled across the globe to expose and represent the Belgrade Waterfront-model and advertise the pre-sale of the apartments also implies that the project enables them to develop symbolic capital in the arena of the global wealth elite. These softer and harder geopolitical gains for this group are in fact much more explicit than the possible eventual economic gains, thus making Belgrade Waterfront an experimental, rather than a speculative entrepreneurial project.

This paper has illustrated that there are many similar features between Belgrade Waterfront and large-scale TREDs from elsewhere, be it developed by UAE-based companies or not. Alongside other TREDs, the project entails a number of features that could be characterized as "experimental-investor urbanism", which should be seen as a phenomenon that becomes increasingly widespread. Compared to more "traditional" cases of speculative and neoliberal urban entrepreneurialism, experimentalinvestor urbanism is even more explicitly transnational as well as (geo)political, and frequently closely affiliated with importing and exporting authoritarian modes of urban development. They can, in other words, hardly be understood by solely looking at economic drivers. Lastly, it should be noted that Belgrade Waterfront differs from many of its counterparts in at least one important aspect. At the time of writing, the first two residential towers ("BW Residences") have just been finished, while, along with 
the preparation of land for several other buildings, another two towers ("BW Vista") and the shopping mall ("BW Gallery") are currently under construction. While it is too early to tell to what extent the Belgrade Waterfront-site will eventually resemble its original design, future research on this topic should critically and systemically assess why some experimental TREDs materialize while others do not.

\section{Conclusion}

Harvey's (1989) notion of urban entrepreneurialism has been a widely-discussed concept within urban studies-related academic disciplines for the past thirty years. While it indeed seems to be the case that speculative urban development agendas focusing on eyecatching architecture, high-end infrastructure and growth are still ongoing, this paper has shown how the growth coalitions behind them are becoming increasingly transnational. Three decades of neoliberalism, alongside the rise of new wealth elites throughout the Global East, have subsequently led to changing features, as well as shifting geographies of large-scale transnational real estate development projects, which has been referred to in this paper as TREDs. The United Arab Emirates, and particularly Dubai, albeit not being exceptional, seem to be exemplary in this regard. Not only have UAEbased companies been involved in many TREDs across the globe from the beginning of the new century onwards; Dubai also counts as a popular object of inter-referencing when it comes to political elites' world city-entrepreneurial aspirations.

While large-scale urban development projects have previously been described as being non-democratic and often "exceptional" in terms of their implementation (Roy \& Ong, 2011; Swyngedouw et al., 2002), contemporary TREDs that are either directly or indirectly influenced to what has been described here as the "Dubai-model", expose new degrees of authoritarian urban development. When political elites invite UAE-based developers to bring in both capital investment and expertise to develop a large-scale urban project, they inevitably also import their habits in terms of top-down and nontransparent forms of decision-making. This has been illustrated by highlighting the case of Belgrade Waterfront in Serbia, a project that is but one element of a wider bilateral deal between both countries' respective central governments. Through a specific focus on the agency behind the project, we argue that for the majority of the stakeholders, (geo) political drivers play a key role alongside (geo)economic ones. These can relate to strategic military or trade agreements, but also to gaining symbolic capital in order to assert one's global visibility or domestic power position. These findings correspond to observations regarding recent TREDs emanating from other geographic contexts.

In order to adapt our academic lenses to contemporary political-economic trends throughout the globe, there is a need to sharpen and extend existing structural economic and urban theories and perspectives by adding new subcategories to them. While certain concepts from the late 1980s such as "growth-coalitions" and "urban entrepreneurialism" still offer useful analytical approaches, one should be aware that urban development in the 21st century has in many cases become even more complicated, especially when projects contain transnational elements as they nowadays often do. Looking at TREDs as being cases of experimental-investor urbanism, while assessing to what extent these are related to the widespread implementation of increasingly authoritarian political-urban 
regimes, could be a useful first step in order to expand our insights on the inter-relation between globalization, capital, ideology and urban development.

\section{Note}

1. Apart from a few digital ones.

\section{Acknowledgments}

The author would like to thank Ben Derudder and Tim Rottleb for their feedback on an earlier version of this paper. He is also grateful to the three anonymous reviewers of this journal for their helpful comments and suggestions.

\section{Disclosure statement}

No potential conflict of interest was reported by the author.

\section{References}

Acuto, Michele. (2010). High-rise Dubai urban entrepreneurialism and the technology of symbolic power. Cities, 27(4), 272-284.

Adham, Khaled. (2014). Modes of urban diffusion: Culture, politics and the impact of the recent urban developments in the Arabian Gulf Cities on Cairo's vision 2050. In Steffen Wippel, Katrin Bromber, Christian Steiner, \& Birgit Krawietz (Eds.), Under construction: Logics of urbanism in the Gulf Region (pp. 233-246). Surrey: Ashgate Publishing Limited.

Akhavan, Mina. (2019). Gateway: Revisiting Dubai as a Port City. In Harvey Molotch \& Davide Ponzini (Eds.), The New Arab Urban: Gulf cities of wealth, ambition, and distress (pp. 175-193). New York: New York University Press.

Appel, Hannah. (2012). Offshore work: Oil, modularity, and the how of capitalism in Equatorial Guinea. American Ethnologist, 39(4), 692-709.

Avermaete, Tom. (2012). 'Neues Bauen in Afrika': Displaying East and West German architecture during the Cold War. The Journal of Architecture, 17(3), 387-405.

Barthel, Pierre-Arnaud. (2014). Global Waterfronts in the Maghreb: A mere replication of Dubai? Case studies from Morocco and Tunisia. In Steffen Wippel, Katrin Bromber, Christian Steiner, \& Birgit Krawietz (Eds.), Under construction: Logics of urbanism in the Gulf Region (pp. 247-258). Surrey: Ashgate Publishing Limited.

Barthel, Pierre-Arnaud, \& Vignal, Leila. (2014). Arab Mediterranean megaprojects after the 'spring': Business as usual or a new beginning? Built Environment, 40(1), 52-71.

Beaverstock, Jonathan V., Hubbard, Philip, \& Short, John Rennie. (2004). Getting away with it? Exposing the geographies of the super-rich. Geoforum, 35(4), 401-407.

Bennett, Oliver (2018, September 10). Why Egypt is building a brand new mega capital city. The Independent. Retrieved from http://www.independent.co.uk

Bhan, Gautam. (2014). The real lives of urban fantasies. Environment and Urbanization, 26(1), 232-235.

Bogaert, Koenraad. (2018). Globalized authoritarianism and the new Moroccan city. Middle East Report, 48(287), 6-10.

Bok, Rachel. (2018). 'By our metaphors you shall know us': The 'fix' of geographical political economy. Progress in Human Geography, 43(6), 1087-1108.

Brill, Frances, \& Reboredo, Ricardo. (2018). Failed fantasies in a South African context: The case of Modderfontein, Johannesburg. Urban Forum, 30, 171-189. 
Bromber, Katrin, Krawietz, Birgit, Steiner, Christian, \& Wippel, Steffen. (2014). The Arab(ian) Gulf: urban development in the making. In Steffen Wippel, Katrin Bromber, Christian Steiner, \& Birgit Krawietz (Eds.), Under construction: Logics of urbanism in the Gulf Region (pp. 1-16). Surrey: Ashgate Publishing Limited.

Brorman Jensen, Boris. (2014). Masdar City: A critical retrospection. In Steffen Wippel, Katrin Bromber, Christian Steiner, \& Birgit Krawietz (Eds.), Under construction: Logics of urbanism in the Gulf Region (pp. 45-54). Surrey: Ashgate Publishing Limited.

Buckley, Michelle, \& Hanieh, Adam. (2014). diversification by urbanization: Tracing the property-finance nexus in Dubai and the Gulf. International Journal of Urban and Regional Research, 38(1), 155-175.

Büdenbender, Mirjam, \& Golubchikov, Oleg. (2016). The geopolitics of real estate: Assembling soft power via property markets. International Journal of Housing Policy, 17(1), 75-96.

Cain, Allan. (2014). African urban fantasies: Past lessons and emerging realities. Environment and Urbanization, 26(2), 561-567.

Choplin, Armelle, \& Franck, Alice. (2014). Seeing Dubai in Khartoum and Nouakchott: 'Gulficiation' on the margins of the Arab world. In Steffen Wippel, Katrin Bromber, Christian Steiner, \& Birgit Krawietz (Eds.), Under construction: Logics of urbanism in the Gulf Region (pp. 271-284). Surrey: Ashgate Publishing Limited.

Cirolia, Liza Rose. (2014). (W)Escaping the challenges of the city: A critique of Cape Town's proposed satellite town. Urban Forum, 25(3), 295-312.

Clerc, Valérie, \& Hurault, Armand. (2010). Property investments and prestige projects in Damascus: Urban and town planning metamorphosis. Built Environment, 36(2), 162-175.

Cohen, Benjamin J. (2009). Sovereign wealth funds and national security: The great tradeoff. International Affairs, 85(4), 713-731.

Cowen, Deborah, \& Smith, Neil. (2009). After geopolitics? From the geopolitical social to geoeconomics. Antipode, 41(1), 22-48.

Datta, Ayona. (2015). New urban utopias of postcolonial India: 'Entrepreneurial urbanization' in Dholera smart city, Gujarat. Dialogues in Human Geography, 5(1), 3-22.

Dixon, Megan. (2010). Emerging Chinese role in shaping St. Petersburg's urban landscape: Interscalar investment strategies in the development of a residential megaproject. Eurasian Geography and Economics, 51(6), 803-819.

Elsheshtawy, Yasser. (2019). Real estate speculation and transnational develoment in Dubai. In Harvey Molotch \& Davide Ponzini (Eds.), The New Arab Urban: Gulf Cities of wealth, ambition, and distress (pp. 235-255). New York: New York University Press.

Emaar. (2017). A new era of development [Annual Report 2017]. Retrieved from www.emaar.com

fDi Intelligence. (2016). The fDi report 2016. London: The Financial Times Ltd.

fDi Intelligence. (2017). The fDi report 2017. London: The Financial Times Ltd.

fDi Markets. (2003-2014). Real estate [fDi Markets]. Retrieved from www.fdimarkets.com

Fernandez, Rodrigo, Hofman, Annelore, \& Aalbers, Manuel B. (2016). London and New York as a safe deposit box for the transnational wealth elite. Environment and Planning A: Economy and Space, 48(12), 2443-2461.

Flyvbjerg, Bent. (2014). What you should know about megaprojects and why: An overview. Project Management Journal, 45(2), 6-19.

Follmann, Alexander. (2015). Urban mega-projects for a 'world-class' riverfront-The interplay of informality, flexibility and exceptionality along the Yamuna in Delhi, India. Habitat International, 45, 213-222.

Goldman, Michael. (2011). Speculative urbanism and the making of the next world city. International Journal of Urban and Regional Research, 35(3), 555-581.

Golubchikov, Oleg. (2010). World-city-entrepreneurialism: Globalist imaginaries, neoliberal geographies, and the production of new St Petersburg. Environment and Planning A, 42(3), 626-643.

Goodfellow, Tom. (2017). Urban fortunes and skeleton cityscapes: Real estate and late urbanization in Kigali and Addis Ababa. International Journal of Urban and Regional Research, 41(5), 786-803. 
Greenfield, Patrick (2018, January 18). Battersea Power Station to be sold for $£ 1.6 \mathrm{bn}$. The Guardian. Retrieved from http://www.theguardian.com

Grubbauer, Monika, \& Čamprag, Nebojša. (2018). Urban megaprojects, nation-state politics and regulatory capitalism in Central and Eastern Europe: The Belgrade Waterfront project. Urban Studies, 56(4), 649-671.

Haberly, Daniel. (2017). From financialization to vulture developmentalism: South-North strategic sovereign wealth fund investment and the politics of the "quadruple bottom line". In Douglas Cumming, Geoffrey Wood, Igor Filatotchev, \& Juliane Reinecke (Eds.), The Oxford handbook of sovereign wealth funds (pp. 87-122). Oxford: Oxford University Press.

Haila, Anne. (1997). The neglected builder of global cities. In Ove Källtorp, Ingemar Elander, Ove Ericsson, \& Mats Franzén (Eds.), Cities in transformation - Transformation in cities: Social and symbolic change of urban space (pp. 51-64). Avebury: Aldershot.

Haila, Anne. (2000). Real estate in global cities: Singapore and Hong Kong as property states. Urban Studies, 37(12), 2241-2256.

Hanieh, Adam. (2018). Money, markets, and monarchies: The Gulf Cooperation Council and the political economy of the contemporary Middle East. Cambridge: Cambridge University Press.

Harrison, John, \& Hoyler, Michael. (2018). Doing global urban research. London: SAGE.

Harvey, David. (1989). From managerialism to entrepreneurialism: The transformation in urban governance in late capitalism. Geografiska Annaler: Series B, Human Geography, 71 (1), 3-17.

Hertog, Steffen. (2019). A quest for significane: Gulf oil monarchies' international strategies and their urban dimensions. In Harvey Molotch \& Davide Ponzini (Eds.), The New Arab Urban: Gulf Cities of wealth, ambition, and distress (pp. 276-299). New York: New York University Press.

Kanna, Ahmed. (2011). The city as corporation. Minneapolis: University of Minnesota Press.

Keeton, Rachel, \& Nijhuis, Steffen. (2019). Spatial challenges in contemporary African New Towns and potentials for alternative planning strategies. International Planning Studies, 24(3-4), $218-234$.

Kennedy, Loraine, Robbins, Glen, Bon, Bérénice, Takano, Guillermo, Varrel, Aurélie, \& Andrade, Julia. (2014). Megaprojects and urban development in cities of the South (Work Package 2 Thematic Report). Bonn: Chance2Sustain.

Kennedy, Loraine, \& Sood, Ashima. (2016). Greenfield development as Tabula Rasa. rescaling, speculation and governance on India's Urban Frontier. Economic \& Political Weekly, L1(17), 41-49.

Knox, Paul. (2012). Starchitects, starchitecture and the symbolic capital of world cities. In Ben Derudder, Michael Hoyler, Peter J. Taylor, \& Frank Witlox (Eds.), International handbook of globalization and world cities (pp. 275-283). London: Edward Elgar.

Koch, Natalie. (2013). Why not a world city? Astana, Ankara, and geopolitical scripts in urban networks. Urban Geography, 34(1), 109-130.

Koch, Natalie, \& Valiyev, Anar. (2015). Urban boosterism in closed contexts: Spectacular urbanization and second-tier mega-events in three Caspian capitals. Eurasian Geography and Economics, 56(5), 575-598.

Koelemaij, Jorn. (2019). Aspiring global nations? Tracing the actors behind Belgrade' 'nationally important' waterfront. In Stijn Oosterlynck, Luce Beeckmans, David Bassens, Ben Derudder, Barbara Segaert, \& Luc Braeckmans (Eds.), The city as a global political actor (pp. 250-272). Oxford: Routledge.

Lauermann, John. (2018). Municipal statecraft: Revisiting the geographies of the entrepreneurial city. Progress in Human Geography, 42(2), 205-224.

Lefebvre, H. (2003). The urban revolution. Minneapolis: University of Minnesota Press.

Lieto, Laura. (2019). Planning for the hybrid Gulf City. In Harvey Molotch \& Davide Ponzini (Eds.), The New Arab Urban: Gulf Cities of wealth, ambition, and distress (pp. 130-146). New York: New York University Press. 
Molotch, Harvey, \& Ponzini, Davide. (2019). Conclusion: From Gulf Cities onward. In Harvey Molotch \& Davide Ponzini (Eds.), The New Arab Urban: GulfCities of wealth, ambition, and distress (pp. 300-320). New York: New York University Press.

Moser, Sarah. (2019). "Two days to shape the future": A Saudi Arabian node in the transnational circulatoin of ideas about new cities. In Harvey Molotch \& Davide Ponzini (Eds.), The New Arab Urban: Gulf Cities of wealth, ambition, and distress (pp. 213-232). New York: New York University Press.

Müller, Martin. (2018). In search of the Global East: Thinking between North and South. Geopolitics, 1-22. doi:10.1080/14650045.2018.1477757

Murray, Martin J. (2015). "City doubles": Re-urbanism in Africa. In Faranak Miraftab, David Wilson, \& Ken Salo (Eds.), Cities and inequalities in a global and neoliberal world (pp. 92-109). New York: Routledge.

Nam, Sylvia. (2017). Urban speculation, economic openness, and market experiments in Phnom Penh. Positions: East Asia Cultures Critique, 25(4), 645-667.

Nastasi, Michele. (2019). A Gulf of images: Photography and the circulation of spectacular architecture. In Harvey Molotch \& Davide Ponzini (Eds.), The New Arab Urban: Gulf Cities of wealth, ambition, and distress (pp. 99-129). New York: New York University Press.

Olds, Kris. (2001). Globalization and urban change: Capital, culture, and pacific rim mega-projects. Oxford: Oxford University Press.

Oosterlynck, Stijn, Beeckmans, Luce, Bassens, David, Derudder, Ben, Segaert, Barbara, \& Braeckmans, Luc. (2019). The city as a global political actor. Oxford: Routledge.

Paul, Darel E. (2004). World cities as hegemonic projects: The politics of global imagineering in Montreal. Political Geography, 23(5), 571-596.

Peck, Jamie. (2013). Explaining (with) neoliberalism. Territory, Politics, Governance, 1(2), 132-157.

Peck, Jamie. (2014). Entrepreneurial urbanism: Between uncommon sense and dull compulsion. Geografiska Annaler: Series B, Human Geography, 96(4), 396-401.

Percival, Tom, \& Waley, Paul. (2012). Articulating intra-Asian urbanism: The production of satellite cities in Phnom Penh. Urban Studies, 49(13), 2873-2888.

Ponzini, Davide. (2019). Mobilities of urban spectacle: Plans, projects, and investments in the Gulf and beyond. In Harvey Molotch \& Davide Ponzini (Eds.), The New Arab Urban: Gulf Cities of wealth, ambition, and distress (pp. 79-96). New York: New York University Press.

Rapoport, Elizabeth. (2014). Utopian visions and real estate dreams: The eco-city past, present and future. Geography Compass, 8(2), 137-149.

Rapoport, Elizabeth. (2015). Globalising sustainable urbanism: The role of international masterplanners. Area, 47(2), 110-115.

Rapoport, Elizabeth, \& Hult, Anna. (2017). The travelling business of sustainable urbanism: International consultants as norm-setters. Environment and Planning A, 49(8), 1779-1796.

Rogers, Dallas. (2017). Geopolitics of real estate: Reconfiguring property, capital, and rights. New York: Rowman \& Littlefield.

Rogers, Dallas, \& Koh, Sin Yee. (2017). The globalisation of real estate: The politics and practice of foreign real estate investment. International Journal of Housing Policy, 17(1), 1-14.

Roy, Ananya. (2009). Why India cannot plan its cities: Informality, insurgence and the idiom of urbanization. Planning Theory, 8(1), 76-87.

Roy, Ananya, \& Ong, Aihwa (Eds.). (2011). Worlding cities: Asian experiments and the art of being global. Malden, MA: Wiley-Blackwell.

Saito, Asato. (2003). Global city formation in a capitalist developmental state: Tokyo and the waterfront sub-centre project. Urban Studies, 40(2), 283-308.

Searle, Llerena Guiu. (2014). Conflict and Commensuration: Contested Market Making in India's Private Real Estate Development Sector. International Journal of Urban and Regional Research, 38(1), 60-78.

Shatkin, Gavin. (2017). Cities for profit. The real estate turn in Asia's urban politics. Ithaka, NY: Cornell University Press. 
Shin, Hyun Bang, \& Kim, Soo-Hyun. (2016). The developmental state, speculative urbanisation and the politics of displacement in gentrifying Seoul. Urban Studies, 53(3), 540-559.

Sklair, Leslie. (2009). The transnational capitalist class: Theory and empirical research. In Friederike Sattler \& Christoph Boyer (Eds.), European economic elites: Between a new spirit of capitalism and the erosion of state socialism (pp. 497-522). Berlin: Duncker \& Humblot.

Sommerlad, Felix. (2014). Promise and reality in Dubai's architectural design. In Steffen Wippel, Katrin Bromber, Christian Steiner, \& Birgit Krawietz (Eds.), Under construction: Logics of urbanism in the Gulf Region (pp. 91-100). Surrey: Ashgate Publishing Limited.

Stanek, Łukasz. (2012). Introduction: The 'Second World's' architecture and planning in the 'Third World'. The Journal of Architecture, 17(3), 299-307.

Steiner, Christian. (2014). Iconic spaces, symbolic capital and the political economy of urban development in the Arab Gulf. In Steffen Wippel, Katrin Bromber, Christian Steiner, \& Birgit Krawietz (Eds.), Under construction: Logics of urbanism in the Gulf Region (pp. 17-30). Surrey: Ashgate Publishing Limited.

Swyngedouw, Erik, Moulaert, Frank, \& Rodriguez, Arantxa. (2002). Neoliberal urbanization in Europe: Large-scale urban development projects and the new urban policy. Antipode, 34(3), 542-577.

Ulrichsen, Kristian Coates. (2016). The United Arab Emirates: Power, politics and policymaking. New York: Routledge.

Van Leynseele, Yves, \& Bontje, Marco. (2019). Visionary cities or spaces of uncertainty? Satellite cities and new towns in emerging economies. International Planning Studies, 24(3-4), 207-217.

Van Meeteren, Michiel, Derudder, Ben, \& Bassens, David. (2016). Can the straw man speak? An engagement with postcolonial critiques of 'global cities research'. Dialogues in Human Geography, 6(3), 247-267.

Van Noorloos, Femke, \& Kloosterboer, Marjan. (2018). Africa's new cities: The contested future of urbanisation. Urban Studies, 55(6), 1223-1241.

Veignal, Leila. (2014). Dubai on Barada? The making of 'globalized Damascus' in times of urban crisis. In Steffen Wippel, Katrin Bromber, Christian Steiner, \& Birgit Krawietz (Eds.), Under construction: Logics of urbanism in the Gulf Region (pp. 259-270). Surrey: Ashgate Publishing Limited.

Watson, Vanessa. (2014). African urban fantasies: Dreams or nightmares? Environment and Urbanization, 26(1), 215-231.

Wong, Alexandra. (2017). Transnational real estate in Australia: New Chinese diaspora, media representation and urban transformation in Sydney's Chinatown. International Journal of Housing Policy, 17(1), 97-119.

Wright, Herbert (2015, December 10). Belgrade Waterfront: An unlikely place for Gulf petrodollars to settle. The Guardian. Retrieved from http://www.theguardian.com 